\title{
Broad-Based Stakeholder Ownership in Journalism: Co-ops, ESOPs, Blockchains
}

\author{
Nathan Schneider ${ }^{1}$ \\ UNIVERSITY OF COLORADO BOULDER \\ nathan.schneider [AT] colorado.edu
}

\begin{abstract}
This article presents a survey of broad-based stakeholder-ownership models for journalism. The models considered are forms of ownership by employees, associations, audiences, and blends of these. Some of the examples are so new that they have not been, and cannot yet be, comprehensively studied. Yet they bear unique promise for addressing the dual challenges of economic sustainability and perceived accountability that bedevil news media today. Such promise, however, does not guarantee success. While broad-based stakeholder ownership in the news business shows capacity for public accountability, as well as some promise for business sustainability, it is ill-equipped to compete in markets organized to favor investor-owners with far greater capital access. Such ownership models, therefore, will likely require additional policy support to gain and maintain significant market share.
\end{abstract}

Keywords: Journalism, Employee Ownership, Cooperative Business, Media Industry, Media History

\section{Introduction: "Owners Who Will"}

On the first weekend of April 2018, the opinion section of the Denver Post went into open revolt against the paper's owners. Under the headline "News Matters," the cover showed a 2013 photo of the newsroom staff with its departed members-the majority of those pictured, thanks to a series of layoffs-replaced with black silhouettes. A series of accompanying articles took aim at the alleged culprit: the paper's owner, a private-equity fund with considerable news holdings called Alden Global Capital. 
"Denver deserves a newspaper owner who supports its newsroom," the lead editorial explained. "If Alden isn't willing to do good journalism here, it should sell The Post to owners who will."

Area residents sought to pool resources to buy the Post, perhaps along with other Colorado papers that Alden Global Capital owns, but the fund expressed no interest in selling. ${ }^{3}$ That June, a group of former Post reporters announced that they had formed a new startup: the Colorado Sun. ${ }^{4}$ Their business cards declared the project "journalist-owned, ad-free." It formed under Colorado's public benefit corporation statute. The Sun's primary backer was Civil, a blockchain-based journalism initiative, backed in turn by the Ethereum venture studio ConsenSys. Holders of the CVL crypto token would have governance rights over the network. The Sun founders not only formed a new company with new owners, they opted for different kinds of ownership.

The concentration of media-industry ownership and its consequences have long been a concern for media scholars. ${ }^{5}$ But recent efforts to envision options for the future of journalism tend to emphasize emerging business models apart from organizational structures. ${ }^{6}$ Where structure is a consideration, the literature has tended to emphasize the distinction between for-profit and nonprofit, ${ }^{7}$ a distinction that such mechanisms as the Sun's employee ownership and blockchain tokens may conceivably blur. In a political moment that frequently positions professional journalism as an "enemy of the people," ${ }^{8}$ it seems opportune to consider models that bypass mechanisms of elite ownership and control such as wealthy families (e.g., The New York Times), self-perpetuating trusts (e.g., The Guardian), and philanthropy (e.g., ProPublica). While government-managed media can represent a form of meaningful economic democracy, ${ }^{9}$ its accountability to key stakeholders is indirect at best-all the more so when such media are insulated, as they should be, from political pressure. Another kind of indirect accountability arises in media owned by large civil society organizations, which Daniel C. Hallin and Paolo Mancini ${ }^{10}$ term the Democratic Corporatist Model. The legacy considered here bears resemblance to these but remains a distinct strategy for achieving and protecting the practice of public journalism. ${ }^{11}$

Inspired by such cases as the Colorado Sun, this study surveys the field of what I refer to as broad-based stakeholder-ownership models for journalism, including both historical and emerging examples. Considered together, these constitute a legacy in journalism, still very much in development today, of sharing ownership as a means of crafting sustainable businesses with accountability to the public good. The survey focuses on the United States due to its specific regulatory and historical circumstances, although these specifics are presented in an international context.

By stakeholder ownership I mean a kind of firm that is structurally and legally accountable to one or more classes of its most active participants. This follows a distinction in management theory between a firm's shareholders, whose primary relationship to the firm is a financial investment, and stakeholders, who may be employees, customers, or other affected communities whose stake is more than solely financial. ${ }^{12}$ Broad-based is a term used to distinguish, for instance, firms in which large majorities of employees are co-owners from those that offer equity compensation to a relatively narrow set of executives. ${ }^{13}$ Broad-based ownership is a relation that includes, or at least can include, most or all members of a core stakeholder class. It is not merely an elite perk. 
The models considered here are forms of ownership by employees, associations, audiences, and blends of these. Some of the examples are so new that they have not been, and cannot yet be, comprehensively studied. Some have run their course. Yet they may bear unique promise for addressing the dual challenges of economic sustainability and perceived accountability that bedevil news media today. Such promise, however, does not guarantee success. This analysis evaluates two predictions about broad-based stakeholder ownership that appear both among practitioners and in relevant research. Both predictions are relevant to the widely felt economic and social crisis that journalism faces in the United States and in many parts of the world.

The first prediction is that such ownership structures will result in alignments of incentives that result in favorable business outcomes. This stems from findings on greater productivity in employee-owned firms ${ }^{14}$ and member loyalty in diverse forms of cooperatives. ${ }^{15}$ The logic goes that if a group of core stakeholders are also owners of the business, they will have an extra reason to secure its financial health with their patronage.

The second prediction is that broad-based stakeholder ownership will result in greater public accountability than other forms of ownership, including nonprofit models, which often rely on elite donors. Once again, there is evidence to support such a supposition in earlier research on employee ownership and cooperatives. ${ }^{16}$ It stands to reason that a business mainly owned by members of a particular public will have strong incentives to operate in the interests of that public.

This survey indicates that while broad-based stakeholder ownership in the news business shows considerable capacity for public accountability, as well as some promise for business sustainability, it is ill-equipped to compete in markets organized to favor investor-owners with far greater capital access. Such ownership models, therefore, will likely require additional policy support to gain and maintain significant market share.

Although particular cases of broad-based stakeholder ownership in journalism have been considered in depth before ${ }^{17}$ and its contours have been surveyed in passing, ${ }^{18}$ this article presents it as a cohesive legacy, with a past deserving further study and a diverse set of experiments underway today. These experiments are motivated, for instance, by entrepreneurs seeking new strategies for securing audience engagement, community-based financing, and purpose-centered business. As many busy entrepreneurs understandably do, they often lack awareness of lessons they might learn from their antecedents.

\section{Employee Ownership}

Journalism was among the formative industries for the practice of employee ownership in the United States. In the mid-nineteenth century, Horace Greeley used the pages of his New-York Tribune to introduce the British cooperative movement to US readers while also instituting employee profit-sharing and ultimately employee ownership at the paper. ${ }^{19}$ Experiments in employee ownership appeared across many industries during the early twentieth century's conflicts between labor and capital, including at newspapers. Employee ownership took hold, in full or in part, at the New York Sun (1926), the Kansas City Star and 
Times (1926), the Milwaukee Journal (1937), the Hartford Courant (1947), the Cincinnati Enquirer (1952), and US News and World Report (1962). The latter was a spin-off of the Bureau of National Affairs, a publisher of diverse specialized periodicals that became fully employeeowned starting in 1946. Typically, employee ownership arose as a succession strategy, upon a private owner's death or retirement. In addition to the prospect of furthering a paper's local ownership and public mission, doing so could enable outgoing owners to avoid inheritance taxes.

All this was before federal law began to accommodate employee stock-ownership plans, or ESOPs, beginning in the 1970s. The recognition largely resulted from the efforts of corporate lawyer Louis O. Kelso, who developed the technique of a leveraged ESOP; through it, a company could finance the sale of shares to a trust on behalf of its employees, not with their own cash but with debt backed by the expectation of future productivity. Kelso first demonstrated his model in a 1956 deal that converted Peninsula Newspapers, owner of the Palo Alto Times and other regional publications, to full employee ownership. In just over eight years, the trust paid off its loan. Kelso later wrote, "The Peninsula Newspapers' ESOP became the Trojan Horse for democratizing American capitalism." ${ }^{20}$

A 1974 reform to the tax code governing employee benefits, proposed by Democratic senator Russell Long under Kelso's tutelage, streamlined the taxation of ESOP trusts, making them a more attractive means of ownership succession or financing growth; in 1984, Senator Long gained the support of President Ronald Reagan to improve the incentives for public firms. These changes spurred far more widespread use of ESOPs throughout the economy, now benefiting more than 14 million employees, according to the National Center for Employee Ownership. The policies also ensured that such ownership could be more broad-based than in the past, as it was not limited to those employees with cash on hand.

Full or partial ESOPs took hold, for instance, at the Fairbanks Daily News-Miner (1975), the Wilkes-Barre Citizens' Voice (1978), the New Hampshire Union Leader (1979), the Omaha World-Herald (1979), the Peoria Journal Star (1984), the Monroe News (1995), the Idaho Falls Post Register (1998), the Chicago Tribune (2007), and the Portland Press Herald and Maine Sunday Telegram (2009). In addition, employee ownership was widespread among printing shops, which often produced their local paper. ${ }^{21,22}$ Several regional radio broadcasters adopted employee ownership as well.

Employee ownership offered benefits for news organizations such as retaining local control, ${ }^{23}$ incentivizing job performance and monitoring, ${ }^{24}$ retaining talent,${ }^{25}$ and accessing capital. ${ }^{26}$ It would seem to protect the professional standards of journalists from outside profit-seekers while retaining incentives for economic success. It would also seem to resist the allure of corporate consolidation, from which employees typically stand to gain less than investors. And yet among the publications listed above, before or after the advent of Kelso's ESOP, none remains substantially employee-owned as of this writing. Even when four of these ESOPs were still intact, Fedler and Pennington ${ }^{27}$ concluded, "Despite journalists' yearning for ownership and criticisms of chains, the concept of employee ownership seems to have failed." 


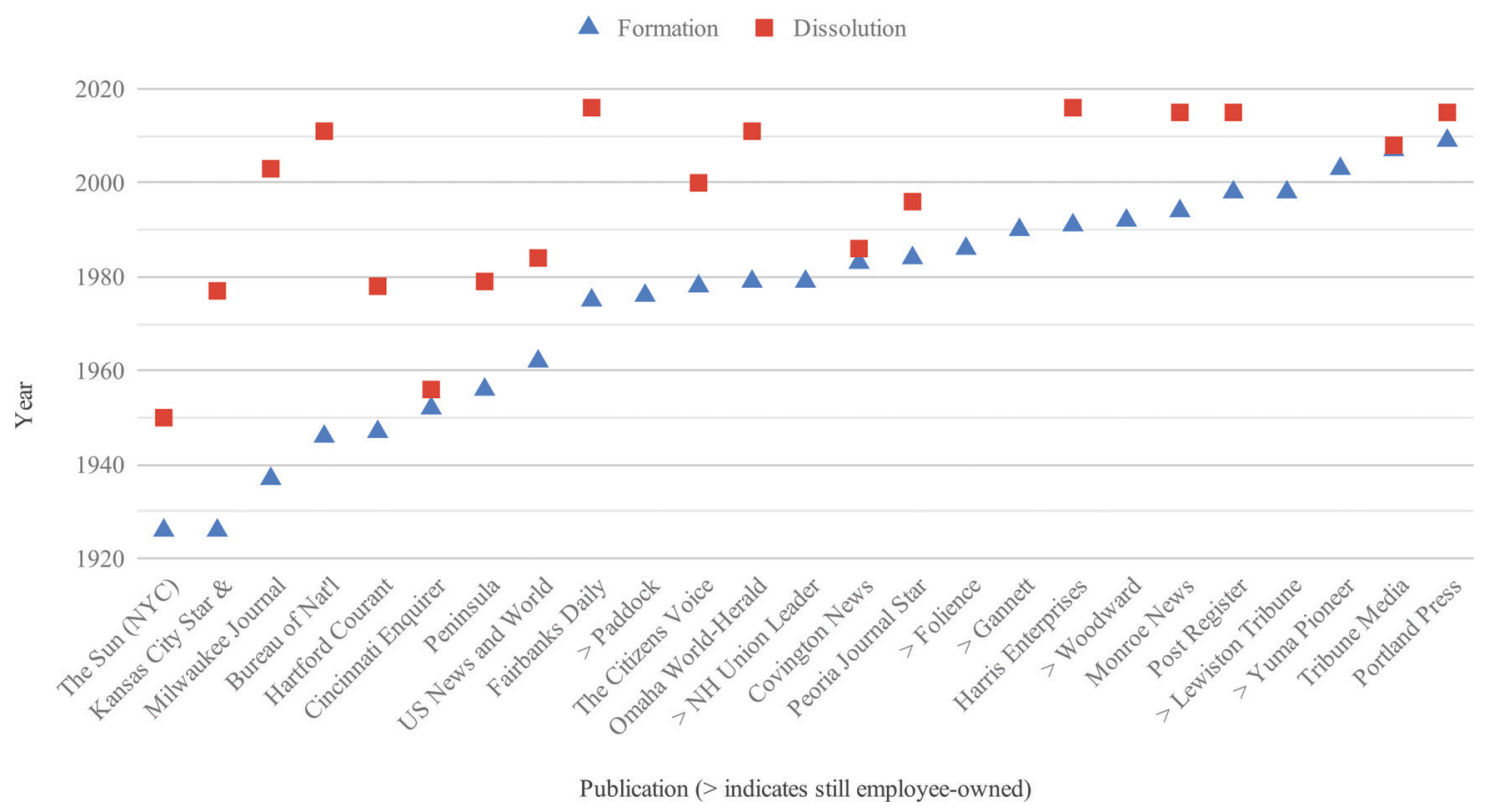

Figure 1. Employee ownership in US news organizations.

Some US news producers remain employee-owned. For the most part, they are diversified organizations that include newspapers among other holdings. The fully employee-owned firm Folience operates the Gazette of Cedar Rapids and the Fairfield Ledger, along with an advertising agency and an ambulance manufacturer. Also in Iowa, Woodward Communications owns several newspapers, including the Dubuque Telegraph Herald, and six radio stations in Wisconsin. The New Hampshire Union Leader ESOP retains a minority stake, as do the employees of the conglomerate Gannett. At least one firm is actually expanding employee ownership; the namesake family of the suburban Chicago-based Paddock Publications sold its remaining stake to the ESOP the company has had since 1976. It became fully employeeowned in 2018. In Paddock's flagship paper, the Daily Herald, CEO Doug Ray was quoted referring to the transaction as "one of those win-win situations in our business." ${ }^{28} \mathrm{He}$ added, "I suspect it will be the envy of the industry, and certainly the employees in our industry."

The specificity and complexity of these cases make it difficult to identify a general explanation. One possibility is the 1989 federal omnibus budget that cut estate tax benefits for ESOPs, slowing the formation of new ESOPs generally ${ }^{29}$; the rate of news ESOP formation, however, remained relatively steady between 1980 and the rise of the competition from the internet economy in 2000 (the year that Craigslist began expanding beyond San Francisco). The most significant cause for the decline in employee ownership among US newspapers was surely the decline in newspapers generally. Closure and consolidation have been a norm across the industry. Yet, despite correlations between employee ownership and resilience in other industries, ${ }^{30}$ such arrangements did not appear to weather journalism's difficulties well. ESOP trusts place significant obligations on a company to repurchase the stock of retiring employees; trusts established during more lucrative times could plausibly leave insufficient 
capital to invest in the digital turn, especially after the 2008 financial crisis. Faced with dwindling stock value, also, ESOP trustees can be required to accept acquisition offers if that will deliver superior returns to the trust's beneficiaries.

In itself, the fact of widespread buyouts among news ESOPs is not necessarily a bad thing; stock ownership meant that employees directly benefited when the Tribune Company bought Peninsula Newspapers in 1978, or when Morton Zuckerman bought US News and World Report in 1984, ${ }^{31}$ or when Warren Buffett bought the Omaha World-Herald in 2011. If part of the hope in employee ownership is to prevent conglomeration and outside ownership, the pecuniary temptations of such buyouts have outweighed it. And many journalists still shudder at the Tribune Company's ill-fated 2007-2008 ESOP, which ended in a painful bankruptcy.

Employee ownership has been a notable phenomenon in the news business internationally as well. In France, Le Monde and Libération have been significantly employee-owned in the past, but neither remains so anymore; Der Spiegel in Germany is about half owned by its print employees; and Il Manifesto in Italy is owned by a cooperative of journalists. One of Uruguay's largest newspapers, La Diaria, formed in 2010 as a worker cooperative. Co-ops are more widespread among smaller outlets, such as the Hullabaloo Publishing Workers Co-operative in Saskatchewan, Canada, which publishes two alternative papers, and the German Stadtrevue. In some places, a period of crisis has led to opportunity. The failure of a major Greek newspaper led to the founding of the cooperative Efimerida ton Syntakton, or Journalists' Newspaper, in 2012. ${ }^{32}$ Just as workers took over abandoned factories after Argentina's 2001 economic crisis, several troubled news organizations there have been "recovered" by their employees in recent years. ${ }^{33}$ In the case of Tiempo Argentino, for instance, a workplace occupation led to the leading newspaper's reinvention in 2016 under the ownership of more than one hundred journalists.

These cases occur in diverse legal, cultural, and political contexts, and all forms of employee ownership are not created equal. ESOPs, for instance, are trusts that hold part or all of a stock corporation, not corporate entities in themselves. The enabling legislation also regards them as primarily retirement benefits. Their oversight is the job of a trustee, usually hired by company management rather than by employees themselves, while worker co-ops tend to involve significant opportunities for employees to participate in governance. ESOPs, however, can have access to financing options inhospitable to co-ops, which has enabled them to become quite widespread. Ownership, depending on the context, involves differing rights and responsibilities. Yet new employee-ownership trust models are emerging that attempt to combine the best of each, such as by mixing ESOPs with benefit corporation status ${ }^{34}$ and features of cooperative governance $^{35}$ or by replacing the ESOP with another, more flexible kind of employee-benefiting trust. ${ }^{36}$

Employee ownership became a popular option for news organizations, particularly during prosperous times. But the track record in times of stress is mixed-and in the United States, mainly poor. This is the form of broad-based stakeholder ownership that has been most extensively tried, particularly due to the tax and financing advantages of ESOPs. Sustainability under difficult conditions, however, may require turning to stakeholders beyond the newsroom. 


\section{Association Ownership}

Probably the most successful example of broad-based stakeholder ownership is that of cooperatives or similar associations made up of constituent news organizations. These are less noticeable to audiences than an employee-owned local newspaper, since they operate in the background, as infrastructure more than as product. But as infrastructure, the significance of these firms is difficult to understate. Associated Press,${ }^{37}$ for instance, claims that "more than half the world's population sees our content every day." This kind of stakeholder ownership has proved effective and resilient, providing insulation from temptations like polarization and exaggeration, economies of scale for smaller news outlets, and incentives to protect and expand the diversity of existing news media. But it remains unclear how useful this model can be beyond a handful of utility-scale institutions.

Associated Press formed in the 1840s as a conspiracy among competing New York City newspapers to share limited resources, such as horse-borne reports from the Mexican front and telegraph cables from Europe. ${ }^{38}$ Member organizations could both receive and contribute news reports through the network. It evolved through various structures in the ensuing decades, as member and client publications vied for influence; a 1945 Supreme Court ruling established it as a (relatively) open-membership cooperative of US news organizations. By then, it had prevailed over several aggressive, profit-seeking competitors, including the Scripps-owned United Press and Hearst's International News Service. The cooperative model enabled scale together with insulation from short-term pressures, and in the long term this amounted to a competitive advantage.

Such patterns appear outside the United States as well. Reuters (founded in 1851), the United Kingdom's Press Association (1868), Agence France-Presse (1869), and the Press Trust of India (1947) have all employed similar structures. The Press Association and Press Trust are, like Associated Press, directly owned by member companies. Reuters was a closely held business until the Press Association bought it in the 1920s, only to sell it to another association of news organizations, which converted it to a publicly traded company in 1984. (By then, it was becoming a financial data firm at least as much as a news agency.) Agence France-Presse is ostensibly a government entity, but its controlling board includes significant representation from the media outlets that it serves.

Smaller organizations have attempted to employ models like these as well. The Mutual Broadcasting System, one of the major radio networks in the United States during the 1930s and 1940s, was owned jointly by several broadcasters and served affiliate stations across the country. ${ }^{39}$ It produced such shows as The Shadow and Lone Ranger, and thrived in the heyday of radio, but its lean structure and reliance on member stations for content left Mutual poorly equipped for a pivot to television. The company demutualized in 1952. Individual media producers have formed cooperative associations as well, such as Magnum, through which photographers like Robert Capa and Henri Cartier-Bresson sold their journalistic work. A newer iteration of this model, Stocksy United, was among the first examples of an online "platform cooperative, ${ }^{40}$ enabling its artist-owners to sell stock photos and videos on their own terms.

Perhaps such associations could have a role in strengthening embattled community news organizations, delivering economies of scale to small producers as Associated Press has for 
more than a century and a half, and better. For instance, the Knight Foundation, the Ford Foundation, and others backed the development of a Detroit Journalism Cooperative, made up of local news outlets, to jointly cover the aftermath of the city's 2013 bankruptcy. Another philanthropic venture, the Colorado Media Project, has convened numerous Colorado publications, including the Sun, into a "value network" to share resources with each other. ${ }^{41}$ In a report exploring the prospects for cooperative models in journalism, Jo Ellen Green Kaiser ${ }^{42}$ highlights the promise of associations over other kinds of co-ops, but also warns that, in some US media circles, the longstanding governance troubles of the cooperative-like Pacifica Network of community radio stations have become cause for trepidation.

A new wave of associations, focused on the shared needs of news organizations in the digital economy, could offer the efficiencies of corporate conglomeration without the loss of local control and accountability. They could also be a means of aggregating capital. Associations present an alternative to BuzzFeed founder Jonah Peretti's for mergers among online news platforms to challenge Big Tech. ${ }^{43}$ But if the earlier associations are any guide, this approach may not cause a shift in public trust in the news media; associations tend to operate in the background, without the involvement or even knowledge of their audiences.

\section{Audience Ownership}

Bound up in the challenge that the digital turn has posed to the economy of journalism, there has been the promise of a more direct, interactive, lucrative opportunity. The so-called Web 2.0 lured away newspaper advertisers with fine-grained targeting and subscribers with free content, but its comment boxes and citizen journalists and social media were supposed to enable a new order. Through savvy engagement and the magic of crowdfunding, the tantalizing story went, journalists could find new revenue streams from their ever-closer relationships with audiences. An "ethic of participation" 44 became commonplace among those devising the future of the profession-an "open source" 45 and "reciprocal" ${ }^{\prime 6}$ kind of news. But such participation has typically not involved any kind of ownership relation.

Talk of ownership was mostly missing from the internet cultures of the early 2000s; rule by founder, venture capitalist, and software were benevolent enough at first to go unquestioned. Journalists were getting in on the game, too, with tech-style venture deals backing publications such as BuzzFeed, Vice, and Vox. But tech giants have endured mounting scrutiny, and prominent media venture deals have inevitably gone sour. In a series of experiments across North America and Europe, models of ownership-by-audience seek to make good on converting engaged audiences into customer loyalty, sustainable revenue, and capital for growth. When outside investors do not seem to take the news business seriously enough, why not make investors out of the people who do?

There are some precedents. The early consumer-owned cooperative movement in Britain, conventionally dated to a store near Manchester that opened in 1844, saw fit to create a publishing arm that was itself a co-op. What is now known as the Co-operative Press was founded between 1869 and 1871 with a public share offering. ${ }^{47}$ The organization continues to publish Co-operative News, a print and online publication that aims to serve the global co-op movement, with both organizational and individual member-owners. Many US cooperative 
businesses meanwhile distribute magazines to their members, particularly the electricutility cooperatives that operate in rural areas. The legacy of rural co-op development also produced the country's first cooperative newspaper, the Inter-County Leader of northwest Wisconsin, which formed in 1933 during a farmers' strike. It remains one of the two papers that operate through the Inter-County Cooperative Publishing Association, ${ }^{48}$ which also offers commercial printing and web design services. In 1937, the Greenbelt Cooperator began as a kind of community newsletter for the New Deal planned community of Greenbelt, Maryland. The subscriber-owned paper, which has published continuously ever since, changed its name to the Greenbelt News Review in the 1950s and won an important press freedom case before the Supreme Court in $1970 .{ }^{49}$

Audience ownership has tended to appear among communities with ideological commitments that incline toward it. For instance, the influential lay-Catholic magazine Jubilee got its start in 1953 with a US\$40,000 reader stock offering that required two founders to register as stockbrokers and obtain permission from the Securities and Exchange Commission. ${ }^{50}$ Jubilee's notion of sharing ownership broadly took explicit inspiration from papal encyclicals and Clare Hutchet Bishop's All Things in Common, a book of reportage on cooperatives in postwar France. The German leftist newspaper Tageszeitung, facing financial problems, drew on the support and radical leanings of its readership to reorganize as a cooperative in 1991; it has been running comfortably since, now with more than sixteen thousand members capitalizing the company. ${ }^{51}$ In Canada, a network of news websites with a shared newspaper between them, The Dominion, formed in 2007 as the Media Co-op, largely owned by readers; it grew out of the Indymedia movement surrounding anti-World Trade Organization protests, a culture that looked favorably on cooperatives as a political practice. $^{52}$

The appeal of audience ownership has lately been growing beyond particular subcultures and seeping into discussions about the future of news in general. Veteran journalist Tom Stites began developing what would be called the Banyan Project in the mid-2000s, with the help of a fellowship at Harvard University's Berkman Center for Internet and Society. The idea was to seed a replicable model for local, online news cooperatives, owned and capitalized by community members. The first instance of the model, Haverhill Matters in Haverhill, Massachusetts, ${ }^{53}$ began development in 2012, starting with a community calendar. ${ }^{54}$ Meanwhile, two news publishers in affluent regions of the San Francisco Bay Area, the website Berkeleyside and the Sonoma West newspaper group, used the regional mechanism of a direct public offering to raise capital from readers. ${ }^{55}$ The technology blog Hacker Noon raised just over US\$1 million in an equity crowdfunding round enabled by the federal 2012 JOBS Act. ${ }^{56}$ Although short of full-on cooperatives, such share offerings position community members to benefit financially from the publications' success alongside other owners.

Probably the best-known example of a successful, durable, audience-owned enterprise in the United States is the Green Bay Packers, which began selling shares to fans in 1923. (Today it is not a stretch to classify a sports franchise as a media company.) A "poison pill" in its bylaws, through which the proceeds of a buyout would go to local charities rather than to stockholders, has prevented the team from moving to a larger market. The similarity between sports teams and local news organizations began to be noticed in the United Kingdom by Dave Boyle, a consultant who had been converting teams into community cooperatives. 
Troubled local businesses like pubs and restaurants were doing the same thing. Dave Boyle argued that the community-ownership model could be "a co-operative solution to the media crisis." 57

Several such experiments have begun with the help of Boyle's consulting practice and a form of nontransferable, withdrawable capital known in the United Kingdom as "community shares." Investors, who need not be accredited, can earn interest and dividends on their shares, or receive refunds if they withdraw, but they cannot sell shares to others on an open market. Positive News, a stylized magazine of "constructive journalism," raised $£ 263,000$ $(\$ 343,000)$ from around 1,500 people in 2015. The New Internationalist, a magazine on global affairs, was founded in 1973, converted to a worker-owned cooperative in 1992, and then adopted a multi-stakeholder cooperative structure when it raised £704,114 (\$878,000) from 3,409 community-shares investors in $2017 .^{58}$ As part of the deal, these offerings granted investorreaders certain governance rights over the media organizations they now co-own. ${ }^{59}$

Both Positive News and the New Internationalist opted for time-bounded offerings to raise capital for particular investments. Because the shares are not transferable, new potential investors will have to wait until the next offering; in the meantime, past investors will retain governing powers that newer subscribers cannot enjoy. Another audience-owned publication in the United Kingdom, the Bristol Cable, formed as a cooperative in 2015. Its free printed and online editions are supported by more than two thousand members, who pay slidingscale monthly contributions and can participate in annual general meetings. Members can join at will, rather than waiting for a future share offer. This is the model, also, of the People's Press Printing Society, a British socialist organization that publishes the Morning Star newspaper and has operated as a reader-owned cooperative since its founding in 1945. Like Postitive News and the New Internationalist, the Cable and the Morning Star cater to a readership inevitably limited by the expectation of niche commitments. The same could be said for another new audience cooperative, the Belgian investigative magazine Médor, which opened in 2015. None is a publication of record, so to speak.

As with employee ownership at the time Peninsula Newspapers adopted it, audience ownership remains largely untested as a strategy for supporting large, sustainable news organizations. There are reasons to believe in its promise. Nonprofit public radio stations in the United States successfully rely on audience financial support. The prospect of temporarily parking capital in a media organization may be more attractive to some committed audience members than making outright donations. And just as employee ownership tends to deliver productivity benefits, audience ownership incentivizes loyal, evangelistic audiences. Audiences may be an especially appropriate stakeholder class for ensuring economic viability and legitimacy; they are in a position to advocate for their publication among potential customers, and they appear to be less of a rarefied elite than professional journalists or wealthy owners.

On the contrary, audience members' small investments and limited direct participation may render them less effective at monitoring performance than employees, private owners, or institutional investors. (A well-designed role for trustee oversight could address this.) It is also unclear whether audience investment is sufficiently scalable to meet the capital needs of a major regional or national publication, especially during turbulent times. 
Louis Kelso, together with his collaborator Patricia Hetter Kelso, proposed several other stock-ownership plans in addition to the ESOP. The one especially relevant here is what they called the consumer stock-ownership plan, or CSOP. "The CSOP technique," they wrote, "is intended to build capital ownership into consumers of public utilities and of other business corporations having monopolistic or oligopolistic consumer relationships." ${ }^{\prime 60}$ As in an ESOP, a CSOP consolidates broad-based ownership into a trust, which simplifies financing and, if the law permits, taxation. The Kelsos envisioned CSOPs for firms that consumers buy from heartily and consistently, such as power companies, grocery stores, department stores, and gas stations. News organizations, which often pay a utility-like role for communities, could be a natural fit as well. It would make for a wider, and perhaps more durable, capital pool than an ESOP alone.

Such an arrangement would likely require policy provisions for taxation and financing comparable to what ESOPs currently enjoy. But the trust structure could make a substantial difference in enabling large news audiences to become news investors with minimal effort or buy-in. The Green Bay Packers model might thus become more available to the news business.

\section{Blended Ownership}

The still-nascent Colorado Sun, with which this article began, does not belong solely to one of the broad-based stakeholder-ownership models discussed above. It may end up belonging to all of them or passing from one to another. As of this writing, the Sun remains owned by its founding journalists. It has also become the first online-only startup admitted as a member of the Associated Press, thus enjoying the benefits of association ownership. ${ }^{61}$ And it began as part of another kind of association, the blockchain-based Civil network, whose token-holders-and thus, in a sense, owners-were intended to be the audience of the network's publications. The Civil Media Company ${ }^{62}$ additionally proposed to create "a media liability insurance company cooperatively owned by newsrooms." On top of a seed grant from Civil, the Sun raised US\$161,493 in a summer 2018 Kickstarter campaign and has an ongoing membership program.

The Sun is not alone in its strategic promiscuity. The aforementioned New Internationalist and Canada's Media Co-op are multi-stakeholder cooperatives, since their shares are divided between reader-investors and employees. This is an increasingly common structure for cooperatives to adopt, especially among platform cooperatives that mediate multisided online markets. ${ }^{63}$ The Kelsos' proposal for the CSOP suggests that such companies would also have ESOPs for their employees, making them another kind of multi-stakeholder organization-and all the more able to access capital by having a more diverse set of instruments at hand. Many news companies with ESOPs are already multi-stakeholder; if they are less than 100 percent employee-owned, they blend employee ownership with other kinds of owners, such as founders and outside investors.

The complexity further proliferates in the case of new blockchain technologies that may shape the future of news economies. Steemit, a Reddit-like social news platform, and the Basic Attention Token, integrated into the Brave web browser, both use tradable 
cryptographic tokens that measure and reward engagement with online content. Such systems blend the identities of producer, consumer, and investor, as well as calling into question certain background assumptions about ownership. Holding the private keys to a given token may or may not accord with the rights associated with an old-world stock certificate. But the potential for blockchain networks to host next-generation cooperatives has been noticed by both scholars and investors. ${ }^{64}$

Even short of blockchain sci-fi, news organizations depend on complex stakeholder relationships-among journalists, advertisers, subscribers, casual readers, investors, and communities as a whole. One prominent proposal for the future of news, Julia Cagé's Saving the Media (2016), recommends reflecting such complex stakeholdership in a system of complex ownership.

Cagé proposes a novel company structure, requiring dedicated legislation, which she calls the "nonprofit media organization," or NMO. She takes inspiration from the capacity of nonprofit universities to accumulate and reinvest large endowments, combined with the governance rights of corporate shareholders. Larger investor-donors would contribute capital in exchange for voting rights over the direction of an NMO. But smaller donors could also have voting rights through equity crowdfunding, especially around particular proposals or campaigns, allowing audiences to aggregate the power of their ownership alongside larger investors. For ceding this kind of control, Cage holds that the NMO should receive tax benefits from the government. She summarizes the model as "capitalism, crowdfunding, democracy."

While Cagé's proposal is mainly untested and may require difficult policy interventions to test, it does reflect in ownership a reality that appears to be widely felt-that media organizations are multi-stakeholder institutions of both public and private character. Although short of what Cagé would like to see, experiments in blended ownership, from blockchains to multi-stakeholder cooperatives, will indicate whether involving more diverse kinds of stakeholders as owners can bring benefits that outweigh the costs of adding organizational complexity.

The Civil project attempted an ambitious, much publicized sale of its underlying CVL tokens in the fall of 2018. Less than US\$1.5 million in tokens were purchased-mostly by the Civil Media Company's sole investor, ConsenSys-short of the US\$8-24 million goal. Insiders perceived that barriers of user-interface and user-comprehension prevented more widespread participation, and Civil closed down in $2020 .{ }^{65}$ It was a sobering result for the prospects of a new ownership technology to somehow "save the media" in any easy or automatic fashion.

\section{Conclusion: "A Bundle of Rights"}

Legal conventional wisdom regards ownership as "a bundle of rights," rather than any fixed or static reality. It is flexible and pliable, a medium for creativity and recombination. The varieties of broad-based stakeholder ownership, and the variety of what they have achieved, are testament to this. Employee ownership offered an attractive means for succession planning while ensuring, at least for a time, local control for local institutions. Associations have served 
as essential, reliable utilities that have enabled news organizations of many sizes to access economies of scale without losing their specificity. Audience ownership seems to be offering a way for news organizations to reestablish trust and ties with their communities at a time of peril for the industry. Together, these forms of broad-based stakeholder ownership have enabled practitioners to obtain features of mission orientation possible in nonprofit models without being dependent on philanthropic funding sources. They can access some forms of business finance without having to make sacrifices to their news mission that aggressive investor-owners might demand. This is an attractive balance, but it is not always an easy one.

Employee ownership, although somewhat widespread in the United States by the end of the twentieth century, proved poorly equipped for weathering the crises that befell journalism with the digital turn, the 2008 financial crisis, and the consolidation of advertising revenues in a few online platforms. Audience ownership has yet to prove viable beyond subcultures with substantial shared commitments. Association ownership remains fairly robust, but it may not prove extensible beyond a few well-established, utility-like organizations. As in so many domains subject to promises about blockchain technology's revolutionary potential, it has yet to be salvific for journalism.

The mixed results reviewed here do suggest some lessons. The advent of Louis Kelso's ESOP mechanism, for instance, made employee ownership a more feasible option for news organizations in search of a succession plan than it had been before. The ESOP was easier to comprehend, participate in, and finance than older broad-based employee-ownership options, such as worker cooperatives. But the model did not prove resilient in the face of contraction and buyout offers. Recent experiments on alternative employee-ownership trust structures, independent of retirement benefits regulation, may offer options more flexible than an ESOP. ${ }^{66}$ Developing parallel strategies for consumer trusts could make audience ownership a more plausible strategy for firms seeking to translate audience loyalty into a capitalization opportunity. ${ }^{67}$ The ESOP experience also suggests the need to design such trusts in ways that secure greater capital reserves, to ensure greater resilience in a volatile, high-tech, low-margin industry. In cases where local control of an organization is of paramount importance, it might also be appropriate to introduce poison-pill provisions to disincentivize buyouts even in difficult times, such as the one that has kept the Green Bay Packers in Green Bay.

Although too rarely celebrated, the effectiveness of association ownership even against wellcapitalized competitors suggests that this kind of model may well be worth advancing and redeploying to meet new challenges. In some respects, efforts like Civil and the Banyan Project have attempted to do just that. But they have yet to land on a model that works as powerfully as the news-gathering associations formed in the mid-nineteenth century.

Clever entrepreneurship alone will likely be inadequate to secure the survival of publicserving journalism in competitive markets. Healthy news industries have typically enjoyed some form of subsidy, through mechanisms including direct government funding, nonprofit tax incentives, or reduced postage costs, and such subsidies appear due for a redesign and renewal. Perhaps the appropriate role for broad-based stakeholder ownership is less to ensure market survival than to protect the public mission of public investments. For instance, to qualify for subsidy, news organizations might be required to practice some form of 
broad-based stakeholder ownership and governance to demonstrate that they are meaningfully serving their natural stakeholders. Alternatively, subsidies might flow through democratic public entities, akin to school boards or library districts. ${ }^{68}$ As in the case of the ESOP, a small, careful, and relatively inexpensive policy intervention can trigger rapid, widespread adoption.

Broad-based stakeholder ownership bears promise as a means of protecting the accountability of a media ecosystem, ensuring local control where appropriate, and distributing the economic spoils equitably. Such models do not in themselves guarantee a news-industry revival any more than they protected it from decline. But they should be understood as a cohesive legacy, distinct from for-profit, nonprofit, and state-run news; this legacy persists as a strategy underlying journalistic experiments around the world. The experimenters can benefit from recognizing themselves as part of a larger story, and scholars can better evaluate them with the genre of broad-based stakeholder ownership in mind.

${ }^{1}$ Nathan Schneider is an assistant professor of media studies at the University of Colorado Boulder. His most recent book is Everything for Everyone: The Radical Tradition that Is Shaping the Next Economy.

${ }^{2}$ Sydney Ember, "Denver Post Rebels Against Its Hedge-Fund Ownership," The New York Times: Business Day, April 9, 2018, https://www.nytimes.com/2018/04/07/ business /media/denver-post-opinion-owner.html.

${ }^{3}$ Aldo Svaldi, "Colorado Investor Group Antes \$10 Million Toward Community Effort to Buy the Denver Post," The Denver Post, April 12, 2018, https://www.denverpost. com/2018/04/12/investor-group-raises-funds-denver-post-purchase/.

${ }^{4}$ Jaclyn Peiser, "Goodbye, Denver Post. Hello, Blockchain," The New York Times: Business, June 17, 2018, https://www.nytimes.com/2018/06/17/business/media/ denver-post-blockchain-colorado-sun.html.

${ }^{5}$ Edward S. Herman and Noam Chomsky, Manufacturing Consent: The Political Economy of the Mass Media (NY: Pantheon Books, 1988); Ben H. Bagdikian, The New Media Monopoly (Boston, MA: Beacon Press, 2004); Eli M. Noam, Media Ownership and Concentration in America (Oxford: Oxford University Press, 2009); Robert W. McChesney, Rich Media, Poor Democracy: Communication Politics in Dubious Times (NY: New Press, 2015); Victor Pickard, "Media Ownership," January 4, 2016, https:// doi.org/10.1002/9781118541555.wbiepc206.

${ }^{6}$ Jay Rosen, "The Membership Puzzle Project," 2017, https://membershippuzzle. org/; Elizabeth Hansen, Emily Roseman, Matthew Spector, and Joseph Lichterman, "Business Models for Local News: A Field Scan" (Shorenstein Center on Media, Politics, and Public Policy at Harvard University, September 6, 2018), https:// shorensteincenter.org/business-models-field-scan/.

${ }^{7}$ Patrick Ferrucci, "Exploring Public Service Journalism: Digitally Native News Nonprofits and Engagement," Journalism and Mass Communication Quarterly 94 (1, March 2017): 355-70, https://doi.org/10.1177/1077699016681968; Magda Konieczna, Journalism Without Profit: Making News When the Market Fails (NY: Oxford University Press, 2018). 
${ }^{8}$ Jeff Jarvis, "Trump and the Press: A Murder-Suicide Pact," in Trump's Media War, ed. Catherine Happer, Andrew Hoskins, and William Merrin (Cham: Springer International Publishing, 2019), 23-29, https://doi.org/10.1007/978-3-319-940694 -2.

${ }^{9}$ McChesney, Rich Media, Poor Democracy; Laura Flanders, "Next System Media: An Urgent Necessity" (The Next System Project, October 12, 2017), https://thenextsystem.org/learn/stories/next-system-media-urgent-necessity.

${ }^{10}$ Daniel C. Hallin and Paolo Mancini, Comparing Media Systems: Three Models of Media and Politics (Cambridge: Cambridge University Press, 2004).

${ }^{11}$ Jeremy Iggers, Good News, Bad News: Journalism Ethics and the Public Interest (NY: Routledge, 2018), https://doi.org/10.4324/9780429500145.

${ }^{12}$ R. Edward Freeman, Jeffrey S. Harrison, Andrew C. Wicks, Bidhan L. Parmar, and Simone de Colle, Stakeholder Theory: The State of the Art (Cambridge: Cambridge University Press, 2010); Lynn A. Stout, The Shareholder Value Myth: How Putting Shareholders First Harms Investors, Corporations, and the Public (San Francisco, CA: Berrett-Koehler Publishers, 2012).

${ }^{13}$ Joseph Blasi, Douglas Kruse, and Richard B. Freeman, "Broad-Based Employee Stock Ownership and Profit Sharing: History, Evidence, and Policy Implications," Journal of Participation and Employee Ownership 1 (1, June 11, 2018): 38-60, https://doi. org/10.1108/JPEO-02-2018-0001.

${ }^{14}$ Blasi et al., "Broad-Based Employee Stock Ownership and Profit Sharing."

${ }^{15}$ Svend Albæk and Christian Schultz, "On the Relative Advantage of Cooperatives," Economics Letters 59 (3, June 1, 1998): 397-401, https://doi.org/10.1016/S01651765(98)00068-8; Peter Bogetoft, "An Information Economic Rationale for Cooperatives," European Review of Agricultural Economics 32 (February 1, 2005): 191-217, https://doi.org/10.1093/eurrag/jbi010; Peter Molk, "The Puzzling Lack of Cooperatives," Tulane Law Review 88 (5, May 2014): 899-958; Brent Hueth, "Missing Markets and the Cooperative Firm" (workshop on Producers' Organizations in Agricultural Markets, Toulouse, France, 2014), 22, https://www.tse-fr.eu/sites / default/files/medias/doc/conf/workshop_po/communications/brent_huet. pdf.

${ }^{16}$ David A. Talbot, Kira Hope Hessekiel, and Danielle Leah Kehl, "Community-Owned Fiber Networks: Value Leaders in America," Berkman Klein Center for Internet \& Society Research Publication (Harvard University, 2017), https://dash.harvard. edu/handle/1/34623859; Blasi et al., "Broad-Based Employee Stock Ownership and Profit Sharing"; Andrew Zitcer and Richardson Dilworth, "Grocery Cooperatives as Governing Institutions in Neighborhood Commercial Corridors," Urban Affairs Review 55 (2, March 1, 2019): 558-90, https://doi.org/10.1177/1078087417709999; Keith Taylor, Governing the Wind Energy Commons Renewable Energy and Community Development (Morgantown: West Virginia University Press, 2019), https://muse.jhu.edu/book/65931/.

${ }^{17}$ E.g., Jonathan Silberstein-Loeb, The International Distribution of News: The Associated Press, Press Association, and Reuters, 1848-1947 (Cambridge: Cambridge University Press, 2014). 
${ }^{18}$ For example, Victor Pickard and Josh Stearns, "New Models Emerge for Community Press," Newspaper Research Journal 32 (1, January 2011): 46-62, https://doi. org/10.1177/073953291103200105.

${ }^{19}$ Fred Fedler and Robert Pennington, "Employee Owned Dailies: The Triumph of Economic Self Interest over Journalistic Ideals," International Journal on Media Management 5 (4, January 1, 2003): 262-74, https://doi.org/ $10.1080 / 14241270309390042$.

${ }^{20}$ Louis O. Kelso and Patricia Hetter Kelso, Democracy and Economic Power: Extending the ESOP Revolution Through Binary Economics (Cambridge, MA: Ballinger Publishing, 1986).

21 "Interview on ESOPs in Journalism," August 1, 2018.

${ }^{22}$ Michael Keeling, the former president of the ESOP Association, also suggests that a 1948 IRS private letter ruling from the Internal Revenue Service obtained by the Fairbanks News-Miner prefigured the employee stock-ownership plan's (ESOP) eventual tax treatment. I have been unable to confirm or obtain this document.

${ }^{23}$ Werner J. Severin, "The Milwaukee 'Journal': Employee-Owned Prizewinner," Journalism Quarterly 56 (4, 1979): 783-87; Fedler and Pennington, "Employee-Owned Dailies."

${ }^{24}$ RobertG. Picard and Aldovan Weezel, "Capitaland Control:Consequences of Different Forms of Newspaper Ownership," International Journal on Media Management 10 (1, February 15, 2008): 22-31, https://doi.org/10.1080/14241270701820473.

${ }^{25}$ Donald L. Guimary, "How Newspapers in Alaska Cope with Staff Turnover," Journalism Quarterly 63 (3, September 1986): 627-30, https://doi.org/10.1177/ 107769908606300330.

${ }^{26}$ Picard and Weezel, "Capital and Control."

${ }^{27}$ Fedler and Pennington, "Employee-Owned Dailies."

${ }^{28}$ Robert Feder, "Paddock Family Selling 120-Year Stake in Daily Herald to Newspaper Employees," Daily Herald, September 13, 2018, https://www.dailyherald.com/ business /20180913/paddock-family-selling-120-year-stake-in-daily-herald-tonewspaper-employees.

${ }^{29}$ Jedidiah J. Kroncke, "ESOPs and the Limits of Fractionalized Ownership," University of Chicago Legal Forum 2017 (12, 2018): 40, https://legal-forum.uchicago.edu/ publication/esops-and-limits-fractionalized-ownership.

${ }^{30}$ Fidan Ana Kurtulus and Douglas Kruse, How Did Employee Ownership Firms Weather the Last Two Recessions?: Employee Ownership, Employment Stability, and Firm Survival (Kalamazoo, MI: W.E. Upjohn Institute, 2016), https://muse.jhu.edu/ chapter $/ 2008285$.

${ }^{31}$ In this case, however, the employees sued for more.

${ }^{32}$ Eugenia Siapera and Lambrini Papadopoulou, "Entrepreneurialism or Cooperativism?" Journalism Practice 10 (2, February 17, 2016): 178-95, https://doi.org/10.10 80/17512786.2015.1125760.

${ }^{33}$ Carolina de Assis, "Argentine Newspapers Closed or Abandoned by Owners Are Recuperated by Workers' Cooperatives," Knight Center for Journalism in the Americas, Journalism in the Americas Blog, March 21, 2018, https://knightcenter. utexas.edu/blog/00-19412-argentine-newspapers-closed-or-abandoned-own ers-are-recuperated-workers-cooperatives. 
${ }^{34}$ Nancy Kurland, "ESOP Plus Benefit Corporation: Ownership Culture with Benefit Accountability," California Management Review 60 (4, August 1, 2018):51-73, https:// doi.org/10.1177/0008125618778853.

${ }^{35}$ Martin Staubus, "The ESOP-Erative," Fifty By Fifty: Employee Ownership News, August 17, 2017, https://medium.com/fifty-by-fifty/the-esop-erative-daaa98c1174f.

${ }^{36}$ Christopher Michael, "The Employee Ownership Trust, an ESOP Alternative," Probate E Property 31 (1, 2017): 42-47.

${ }^{37}$ Associated Press, "About Us," Associated Press, October 27, 2018, https://www .ap.org/about/.

${ }^{38}$ Victor Rosewater, History of Coöperative News-Gathering in the United States (NY: D. Appleton, 1930); Menahem Blondheim, News over the Wires: The Telegraph and the Flow of Public Information in America, 1844-1897 (Cambridge, MA: Harvard University Press, 1994); Silberstein-Loeb, The International Distribution of News.

${ }^{39}$ Christopher H. Sterling and John Michael Kittross, Stay Tuned: A History of American Broadcasting (NY: Routledge, 2001); Federal Communications Commission, "Report on Chain Broadcasting," May 1941, http://earlyradiohistory.us/1941cb04.htm.

${ }^{40}$ Nathan Schneider, "An Internet of Ownership: Democratic Design for the Online Economy," The Sociological Review 66 (2, March 2018): 320-40.

${ }^{41}$ Colorado Media Project, "Colorado Newsrooms Chart a Collaborative Future," Colorado Media Project, November 20, 2018, https://coloradomediaproject.com/ blog/2018/11/20/colorado-newsrooms-chart-a-collaborative-future.

42 "Media Cooperatives: Challenges and Opportunities," Medium, Jo Ellen Green Kaiser, February 3, 2019, https://medium.com/@jgksfconsulting/media-cooper atives-challenges-and-opportunities-e6803c0716ae.

${ }^{43}$ Edmund Lee, "Founder's Big Idea to Revive BuzzFeed's Fortunes? A Merger with Rivals," The New York Times: Business, November 19, 2018, https://www.nytimes. com/2018/11/19/business/media/buzzfeed-jonah-peretti-mergers.html.

${ }^{44}$ Seth C. Lewis, "The Tension Between Professional Control and Open Participation," Information, Communication \& Society 15 (6, August 1, 2012): 836-66, https://doi. org/10.1080/1369118X.2012.674150.

${ }^{45}$ Melanie Sill, "The Case for Open Journalism Now" (Annenberg Innovation Lab, University of Southern California, December 2011).

${ }^{46}$ Mark Coddington, Seth C. Lewis, and Avery E. Holton, "Measuring and Evaluating Reciprocal Journalism as a Concept," Journalism Practice 12 (2018):1039-50, https:// doi.org/10.1080/17512786.2018.1493948.

${ }^{47}$ Gillian Lonergan and Adam Shaw, "Co-Operative Press," JISC Archives Hub, 2011, https://archiveshub.jisc.ac.uk/data/gb1499-pres.

${ }^{48}$ Inter-County Cooperative Publishing Association, "About Us," October 14, 2018, http://www.iccpaonline.com/about-us.html.

${ }^{49}$ Heather Elizabeth Peterson, "The Cooperator: An Unofficial History of the Greenbelt News Review," Greenbelt.com, March 17, 1999, http://www.greenbelt.com/gnr/ page1.htm.

${ }^{50}$ Mary Anne Rivera, "Jubilee: A Magazine of the Church and Her People: Toward a Vatican II Ecclesiology," Logos: A Journal of Catholic Thought and Culture 10 (4, 2007): 77-103, https://doi.org/10.1353/log.2007.0036. 
${ }^{51}$ Thomas Doennebrink, "\#BuyTwitter? German Newspaper Taz Has Been There, Done That," P2 P Foundation, October 31, 2016, https://blog.p2pfoundation. net/buytwitter-german-newspaper-taz-done/2016/10/31; "Interview on the Cooperative Model of Tageszeitung," July 20, 2018.

${ }^{52}$ Dawn Paley, "Know Your Co-Op!: An Introduction to the History, Structure, and Funding Model of the Media Co-Op" (The Media Co-op, 2011), https://www.scribd. com/document/83245767/Know-your-Media-Co-op.

${ }^{53}$ The URL is haverhill.matters.coop, setting precedent for a "matters.coop" franchise. 54 "Interview on the Banyan Project," July 16, 2018.

${ }^{55}$ Tim Arango, "In Liberal Wine Country, Turning Newspaper Readers into Shareholders," The New York Times: Business Day, August 26, 2018, https://www. nytimes.com/2018/08/26/business/media/local-newspaper-shareholders. html.

${ }^{56}$ Hacker Noon, "Hacker Noon: The Premier Independent Tech Publication," StartEngine, 2019, https://www.startengine.com/hackernoon.

${ }^{57}$ Dave Boyle, "Good News: A Co-Operative Solution to the Media Crisis," Fresh Ideas (Manchester: Co-operatives UK, 2012), https://www.uk.coop/resources/good news-co-operative-solution-media-crisis.

${ }^{58}$ See a dedicated website at factsandheart.org.

59 "Interview on the New Internationalist Community Shares Offering," July 26, 2018; Hazel Sheffield, "Are Media Coops the Business Model of the Future?" Columbia Journalism Review, September 13, 2018, https://www.cjr.org/business_of_news/ new-internationalist.php; "Interview on the Positive News Community Shares Offering," July 27, 2018.

${ }^{60}$ Kelso and Kelso, Democracy and Economic Power.

61 "Interview on the Colorado Sun," October 23, 2018.

62 "The Civil White Paper," Civil, 2018, http://civil.co/white-paper/.

${ }^{63}$ Schneider, "An Internet of Ownership."

${ }^{64}$ Morshed Mannan, "Fostering Worker Cooperatives with Blockchain Technology: Lessons from the Colony Project," Erasmus Law Review 56 (1,2019): 190-203, http:// www.erasmuslawreview.nl/tijdschrift/ELR/2019/01/ELR_2018_011_003_ 005; Jesse Walden, "Past, Present, Future: From Co-Ops to Cryptonetworks," AndreessenHorowitz,March2,2019,https://a16z.com/2019/03/02/cooperativescryptonetworks /.

${ }^{65}$ Matthew Iles, "What's Next for Civil," Civil, October 16, 2018, https://blog.joincivil. com/whats-next-for-civil-66f2737f5c31.

${ }^{66}$ Michael, "The Employee Ownership Trust, an ESOP Alternative."

${ }^{67}$ Nathan Schneider, "User Trusts: Broad-Based Ownership for Online Platforms," Informatik Spektrum, 2019, https://osf.io/puy5d/.

${ }^{68}$ Simon Galperin, “Journalism Is a Public Service. Why Don't We Fund It Like One?" Columbia Journalism Review, July 19, 2017, https://www.cjr.org/united states_project/local-news-special-service-community-information-districts. php. 


\section{Bibliography}

Albæk, Svend, and Christian Schultz. "On the Relative Advantage of Cooperatives." Economics Letters 59, no. 3 (June 1, 1998): 397-401. https://doi.org/10.1016/S01651765(98)00068-8.

Arango, Tim. "In Liberal Wine Country, Turning Newspaper Readers into Shareholders." The New York Times: Business Day, August 26, 2018. https://www.nytimes. com/2018/08/26/business/media/local-newspaper-shareholders.html.

Assis, Carolina de. "Argentine Newspapers Closed or Abandoned by Owners Are Recuperated by Workers' Cooperatives." Knight Center for Journalism in the Americas. Journalism in the Americas Blog, March 21, 2018. https://knightcenter.utexas.edu/blog/0019412-argentine-newspapers-closed-or-abandoned-owners-are-recuperatedworkers-cooperatives.

Associated Press. "About Us." Associated Press, October 27,2018. https://www.ap.org/about/.

Bagdikian, Ben H. The New Media Monopoly. Boston, MA: Beacon Press, 2004.

Blasi, Joseph, Douglas Kruse, and Richard B. Freeman. "Broad-Based Employee Stock Ownership and Profit Sharing: History, Evidence, and Policy Implications." Journal of Participation and Employee Ownership 1, no. 1 (June 11, 2018): 38-60. https://doi. org/10.1108/JPEO-02-2018-0001.

Blondheim, Menahem. News over the Wires: The Telegraph and the Flow of Public Information in America, 1844-1897. Cambridge, MA: Harvard University Press, 1994.

Bogetoft, Peter. "An Information Economic Rationale for Cooperatives." European Review of Agricultural Economics 32 (February 1, 2005): 191-217. https://doi.org/10.1093/ eurrag/jbi010.

Boyle, Dave. "Good News: A Co-Operative Solution to the Media Crisis." Fresh Ideas. Manchester: Co-operatives UK, 2012. https://www.uk.coop/resources/good-newsco-operative-solution-media-crisis.

Civil Media Company. "The Civil White Paper." Civil, 2018. http://civil.co/white-paper/.

Coddington, Mark, Seth C. Lewis, and Avery E. Holton. "Measuring and Evaluating Reciprocal Journalism as a Concept." Journalism Practice 12 (2018): 1039-50. https://doi.org/10. 1080/17512786.2018.1493948.

Colorado Media Project. "Colorado Newsrooms Chart a Collaborative Future." Colorado Media Project, November 20, 2018. https://coloradomediaproject.com/blog/2018/11/20/ colorado-newsrooms-chart-a-collaborative-future.

Doennebrink, Thomas. "\#BuyTwitter? German Newspaper Taz Has Been There, Done That." P2P Foundation, October 31, 2016. https://blog.p2pfoundation.net/buytwitter-ger man-newspaper-taz-done/2016/10/31. 
Ember, Sydney. "Denver Post Rebels Against Its Hedge-Fund Ownership." The New York Times: Business Day, April 9, 2018. https://www.nytimes.com/2018/04/07/ business/media/denver-post-opinion-owner.html.

Feder, Robert. "Paddock Family Selling 120-Year Stake in Daily Herald to Newspaper Employees." Daily Herald, September 13, 2018. https://www.dailyherald.com/ business /20180913/paddock-family-selling-120-year-stake-in-daily-herald-tonewspaper-employees.

Federal Communications Commission. "Report on Chain Broadcasting," May 1941. http:// earlyradiohistory.us/1941cb04.htm.

Fedler, Fred, and Robert Pennington. "Employee-Owned Dailies: The Triumph of Economic Self Interest over Journalistic Ideals." International Journal on Media Management 5, no. 4 (January 1, 2003): 262-74. https://doi.org/10.1080/14241270309390042.

Ferrucci, Patrick. "Exploring Public Service Journalism: Digitally Native News Nonprofits and Engagement." Journalism and Mass Communication Quarterly 94, no. 1 (March 2017): 355-70. https://doi.org/http://dx.doi.org/10.1177/1077699016681968.

Flanders, Laura. "Next System Media: An Urgent Necessity." The Next System Project, October 12, 2017. https://thenextsystem.org/learn/stories/next-system-mediaurgent-necessity.

Freeman, R. Edward, Jeffrey S. Harrison, Andrew C. Wicks, Bidhan L. Parmar, and Simone de Colle. Stakeholder Theory: The State of the Art. Cambridge: Cambridge University Press, 2010.

Galperin, Simon. "Journalism Is a Public Service. Why Don't We Fund It Like One?" Columbia Journalism Review, July 19, 2017. https://www.cjr.org/united_states_project/localnews-special-service-community-information-districts.php.

Guimary, Donald L. "How Newspapers in Alaska Copewith StaffTurnover."Journalism Quarterly 63, no. 3 (September 1986): 627-30. https://doi.org/10.1177/107769908606300330.

Hacker Noon. "Hacker Noon: The Premier Independent Tech Publication." StartEngine, 2019. https://www.startengine.com/hackernoon.

Hallin, Daniel C., and Paolo Mancini. Comparing Media Systems: Three Models of Media and Politics. Cambridge: Cambridge University Press, 2004.

Hansen, Elizabeth, Emily Roseman, Matthew Spector, and Joseph Lichterman. "Business Models for Local News: A Field Scan." Shorenstein Center on Media, Politics, and Public Policy at Harvard University, September 6, 2018. https://shorensteincenter. org/business-models-field-scan/.

Herman, Edward S., and Noam Chomsky. Manufacturing Consent: The Political Economy of the Mass Media. New York: Pantheon Books, 1988.

Hueth, Brent. "Missing Markets and the Cooperative Firm." Workshop on Producers' Organizations in Agricultural Markets, Toulouse, France, 2014. https://www.tse-fr. eu/sites/default/files/medias/doc/conf/workshop_po/communications/brent_ huet.pdf. 
Iggers, Jeremy. Good News, Bad News: Journalism Ethics and the Public Interest. New York: Routledge, 2018. https://doi.org/10.4324/9780429500145.

Iles, Matthew. "What's Next for Civil." Civil, October 16, 2018. https://blog.joincivil.com/ whats-next-for-civil-66f2737f5c31.

Inter-County Cooperative Publishing Association. "About Us," October 14, 2018. http:// www.iccpaonline.com/about-us.html.

"Interview on ESOPs in Journalism," August 1, 2018.

"Interview on the Banyan Project," July 16, 2018.

"Interview on the Colorado Sun," October 23, 2018.

"Interview on the Cooperative Model of Tageszeitung," July 20, 2018.

"Interview on the New Internationalist Community Shares Offering," July 26, 2018.

"Interview on the Positive News Community Shares Offering," July 27, 2018.

Jarvis, Jeff. "Trump and the Press: A Murder-Suicide Pact." In Trump's Media War, edited by Catherine Happer, Andrew Hoskins, and William Merrin, 23-29. Cham: Springer International Publishing, 2019. https://doi.org/10.1007/978-3-319-94069-4_2.

Kaiser, Jo Ellen Green. "Media Cooperatives: Challenges and Opportunities." Medium. Jo Ellen Green Kaiser, February 3, 2019. https://medium.com/@jgksfconsulting/ media-cooperatives-challenges-and-opportunities-e6803c0716ae.

Kelso, Louis O., and Patricia Hetter Kelso. Democracy and Economic Power: Extending the ESOP Revolution Through Binary Economics. Cambridge, MA: Ballinger Publishing, 1986.

Konieczna, Magda. Journalism Without Profit: Making News When the Market Fails. New York: Oxford University Press, 2018.

Kroncke, Jedidiah J. "ESOPs and the Limits of Fractionalized Ownership." University of Chicago Legal Forum 2017, no. 12 (2018): 40. https://legal-forum.uchicago.edu/ publication/esops-and-limits-fractionalized-ownership.

Kurland, Nancy. "ESOP Plus Benefit Corporation: Ownership Culture with Benefit Accountability." California Management Review 60, no. 4 (August 1, 2018): 51-73. https://doi.org/10.1177/0008125618778853.

Kurtulus, Fidan Ana, and Douglas Kruse. How Did Employee Ownership Firms Weather the Last Two Recessions?: Employee Ownership, Employment Stability, and Firm Survival. Kalamazoo, MI:W.E. Upjohn Institute, 2016. https:/ / muse.jhu.edu/chapter /2008285.

Lee, Edmund. "Founder's Big Idea to Revive BuzzFeed's Fortunes? A Merger with Rivals." The New York Times: Business, November 19, 2018. https://www.nytimes. com/2018/11/19/business/media/buzzfeed-jonah-peretti-mergers.html.

Lewis, Seth C. "The Tension Between Professional Control and Open Participation." Information, Communication \& Society 15, no. 6 (August 1, 2012): 836-66. https://doi. org/10.1080/1369118X.2012.674150. 
Lonergan, Gillian, and Adam Shaw. "Co-Operative Press." JISC Archives Hub, 2011. https:// archiveshub.jisc.ac.uk/data/gb1499-pres.

Mannan, Morshed. "Fostering Worker Cooperatives with Blockchain Technology: Lessons from the Colony Project." Erasmus Law Review 56, no. 1(2019): 190-203. http://www. erasmuslawreview.nl/tijdschrift/ELR/2019/01/ELR_2018_011_003_005.

McChesney, Robert W. Rich Media, Poor Democracy: Communication Politics in Dubious Times. New York: New Press, 2015.

Michael, Christopher. "The Employee Ownership Trust, an ESOP Alternative." Probate $\mathcal{E}$ Property 31, no. 1 (2017): 42-47.

Molk, Peter. "The Puzzling Lack of Cooperatives." Tulane Law Review 88, no. 5 (May 2014): 899-958.

Noam, Eli M. Media Ownership and Concentration in America. Oxford: Oxford University Press, 2009.

Paley, Dawn. "Know Your Co-Op!: An Introduction to the History, Structure, and Funding Model of the Media Co-Op." The Media Co-op, 2011. https://www.scribd.com/ document/83245767/Know-your-Media-Co-op.

Peiser, Jaclyn. "Goodbye, Denver Post. Hello, Blockchain.” The New York Times: Business, June 17, 2018. https://www.nytimes.com/2018/06/17/business/media/denver-postblockchain-colorado-sun.html.

Peterson, Heather Elizabeth. "The Cooperator: An Unofficial History of the Greenbelt News Review." Greenbelt.com, March 17, 1999. http://www.greenbelt.com/gnr/page1.htm.

Picard, Robert G., and Aldo van Weezel. "Capital and Control: Consequences of Different Forms of Newspaper Ownership." International Journal on Media Management 10, no. 1 (February 15, 2008): 22-31. https://doi.org/10.1080/14241270701820473.

Pickard, Victor. "Media Ownership," January 4, 2016. https://doi.org/10.1002/9781118541555. wbiepc206.

Pickard, Victor, and Josh Stearns. "New Models Emerge for Community Press." Newspaper Research Journal 32, no. 1 (January 2011): 46-62. https://doi.org/ 10.1177/073953291103200105.

Rivera, Mary Anne. "Jubilee: A Magazine of the Church and Her People: Toward a Vatican II Ecclesiology." Logos: A Journal of Catholic Thought and Culture 10, no. 4 (2007): 77-103. https://doi.org/10.1353/log.2007.0036.

Rosen, Jay. "The Membership Puzzle Project," 2017. https://membershippuzzle.org/.

Rosewater, Victor. History of Coöperative News-Gathering in the United States. New York: D. Appleton, 1930.

Schneider, Nathan. "An Internet of Ownership: Democratic Design for the Online Economy." The Sociological Review 66, no. 2 (March 2018): 320-40.

Schneider, Nathan. "User Trusts: Broad-Based Ownership for Online Platforms." Informatik Spektrum, 2019. https://osf.io/puy5d/. 
Severin, Werner J. "The Milwaukee 'Journal': Employee-Owned Prizewinner." Journalism Quarterly 56, no. 4 (1979): 783-87.

Sheffield, Hazel. "Are Media Coops the Business Model of the Future?" Columbia Journalism Review, September 13, 2018. https://www.cjr.org/business_of_news/new-interna tionalist.php.

Siapera, Eugenia, and Lambrini Papadopoulou. "Entrepreneurialism or Cooperativism?" Journalism Practice 10, no. 2 (February 17, 2016): 178-95. https://doi.org/10.1080/175 12786.2015.1125760.

Silberstein-Loeb, Jonathan. The International Distribution of News: The Associated Press, Press Association, and Reuters, 1848-1947. Cambridge: Cambridge University Press, 2014.

Sill, Melanie. "The Case for Open Journalism Now." Annenberg Innovation Lab, University of Southern California, December 2011.

Staubus, Martin. "The ESOP-Erative." Fifty By Fifty: Employee Ownership News, August 17, 2017. https://medium.com/fifty-by-fifty/the-esop-erative-daaa98c1174f.

Sterling, Christopher H., and John Michael Kittross. Stay Tuned: A History of American Broadcasting. New York: Routledge, 2001.

Stout, Lynn A. The Shareholder Value Myth: How Putting Shareholders First Harms Investors, Corporations, and the Public. San Francisco, CA: Berrett-Koehler Publishers, 2012.

Svaldi, Aldo. "Colorado Investor Group Antes \$10 Million Toward Community Effort to Buy the Denver Post." The Denver Post, April 12, 2018. https://www.denverpost. com/2018/04/12/investor-group-raises-funds-denver-post-purchase/.

Talbot, David A., Kira Hope Hessekiel, and Danielle Leah Kehl. "Community-Owned Fiber Networks: Value Leaders in America." Berkman Klein Center for Internet \& Society Research Publication. Harvard University, 2017. https://dash.harvard.edu/ handle/1/34623859.

Taylor, Keith. Governing the Wind Energy Commons Renewable Energy and Community Development. Morgantown: West Virginia University Press, 2019. https://muse.jhu. edu/book/65931/.

Walden, Jesse. "Past, Present, Future: From Co-Ops to Cryptonetworks." Andreessen Horowitz, March 2, 2019. https://a16z.com/2019/03/02/cooperatives-cryptonetworks/.

Zitcer, Andrew, and Richardson Dilworth. "Grocery Cooperatives as Governing Institutions in Neighborhood Commercial Corridors." Urban Affairs Review 55, no. 2 (March 1, 2019): 558-90. https://doi.org/10.1177/1078087417709999. 
